\title{
The Value of the Corporate Governance Canon on Chinese Companies
}

\author{
Bryane Michael, University of Hong Kong and \\ Say Goo, University of Hong Kong
}

1 November 2016

\begin{abstract}
China has yet to import the corporate governance "canon" (generally accepted rules as promoting share holder value as well as minority shareholder and other stakeholders' rights) into its Code of Corporate Governance. What effect would Chinese companies' simply adopting such a canon as defined by Hong Kong or other foreign corporate governance practices -- have on their share prices? We look at Mainland Chinese companies listed in Hong Kong, looking at the way their share prices react to economic fluctuations when they have better or worse corporate governance practices. Using a differences-of-differences methodology, that such share prices could/would increase by around $7 \%$-- increasing profits by about $\$ 330$ billion. Yet, a significant part of the distribution of these companies loose money in the short-run. These results provide yet another confirmation that adopting the corporate governance canon can profit companies' investors, but not all of them.
\end{abstract}

Keywords: Chinese corporate governance, differences-in-differences, post-crisis economics. JEL codes: G34, N25, M14

Acknowledgement: We gratefully acknowledge the Hong Kong Theme-Based Research Grant Scheme for support. Faults with the paper belong to us alone. Errors of course remain our own. 
Electronic copy available at: https://ssrn.com/abstract=3101277 


\section{The Value of the Corporate Governance Canon on Chinese Companies}

Bryane Michael, University of Hong Kong and

Say Goo, University of Hong Kong

\section{Introduction}

Why would a corporate manager not want to improve his or her company's corporate governance? For decades, a "canon” of corporate governance reforms, epitomised by the OECD (2015) Principles of Corporate Governance, has dominated thinking about the most value-adding ways to improve corporate governance. Follow these rules and shareholder value will grow. But does it? Especially in emerging markets like China? For decades, scholars like Bai et al. (2004) have tried to quantify the gains from "better" corporate governance in China (with better in quotes because most academics can not agree on what better means in the Chinese context). Yet, using their revenues, profits, or even local stock markets as a gauge of such value suffers from noise like economic slow-downs, individuals' policies, and so forth. What if we look at the data available, both from fancy mathematically driven models and from a raw view of the data...from a controlled, calm place like Hong Kong? Would Mainland companies, with better corporate governance practices, share valuations change differently than those companies with practices that do not follow the OECD canon? What about companies implementing reforms broader than the canon?

We find that Chinese companies adopting the corporate governance canon - as measured by compliance with the Hong Kong Stock Exchange's Code of Corporate Governance - earn 7\% higher returns than those that do not. Such a policy change could increase shareholder value by more than $\$ 330$ billion. The first part of this paper reviews previous works, most finding that better corporate governance pays-off in terms of share holder returns. The second part looks at the effect on Chinese companies' valuations when they "import" foreign corporate governance rules by listing abroad. These studies generally find that such an import correlates with higher share prices. The third part provides yet another confirmation - using a differences-in-differences methodology to estimate the value of the canon. Namely, using Mainland firms listed in China as a baseline, we look at the effects of the Hong Kong Stock Exchange's Code of Corporate Governance on Mainland firms listed in Hong Kong from 2009 to 2012. The final section concludes.

We should highlight some caveats before we begin. First, we spend more time reviewing other studies in-depth in order to provide the reason with the intuitions needed for understanding our own results. We do not provide a perfunctory literature review, getting it out of the way in order to move on to the good stuff. Our review of past studies represents the good stuff that readers will need to form deeper intuitions driving our own results. Second, and similarly, our multidisciplinary paper does not follow the usual path of model building and using the econometric methods in vogue at the time. We purposely keep our analysis descriptive - following the critical school's criticism in the social sciences that heavy econometrics molds the results and obscures the results (Zachariadis and co-authors, 2010; Izurieta, 2017). We do not follow the usual mould of publishable papers. We hope the reader finds this approach a useful example of post-crisis economics. Third, and again consistent with this approach, we do not try to analyse our mean or distribution using fancy econometric tools. Because the evidence about whether corporate governance positively or negatively affects share prices remains so murky, even a simple, robust 
conclusion like ours contributes to the din. Simply put, we can not believe no one has done this kind of differences-in-differences before.

\section{Reviewing the Link between Chinese Corporate Governance and Investor Returns}

How do we know that 'better' corporate governance practices among Chinese firms contribute to higher corporate returns? Figure 1 shows the results of simplistic (and wrong) analysis showing the simple correlation between corporate governance scores and corporate returns. Companies with corporate governance practices conforming to the OECD's 'corpus' of good practices earn higher schools. Foreign companies with the highest corporate governance scores have rates of return just as low as low-scoring Chinese state owed enterprises. Such work supports other findings from academics like Cheung and co-authors' (2008) early econometric work. Their econometric analysis finds no relationship between corporate governance index scores and market valuation. Sector-specific work, such as Fan et al. (2014), looking at corporate governance and the performance of Chinese real-estate companies - similarly find little relationship. At first glance, then, following the corpus seems to have no effect on public investors' returns.

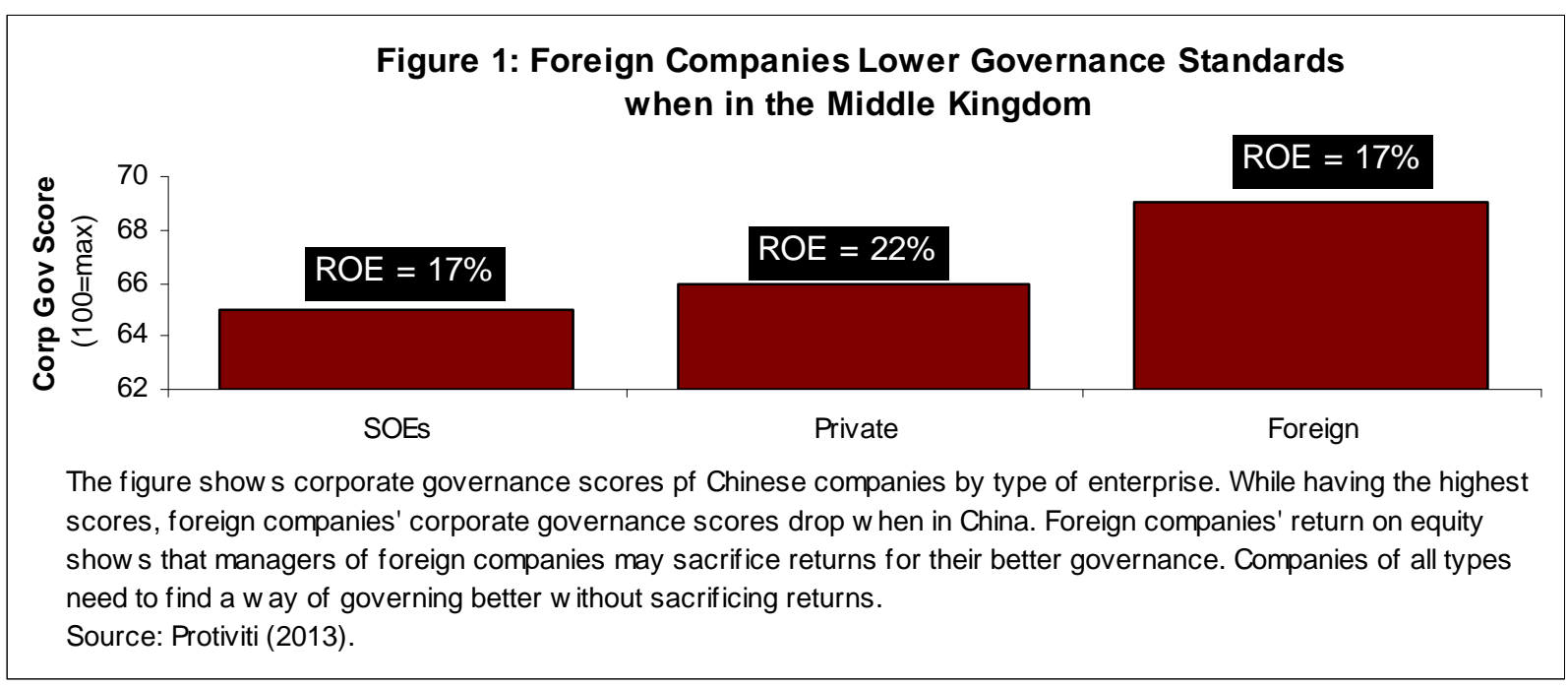

Yet, more credible studies do find a relationship between Chinese firms' corporate governance index values market valuations. Even before looking at these studies, Figure 2 shows an unmistakable relationship between the quality of Mainland companies' corporate governance and their Tobins' $q .{ }^{1}$ The line of best fit seems to show that a one-point increase in corporate governance indicators correlates with a 1 point change in Tobin's $q$ values. Figure 3 shows very similar findings - with changes in market valuations (namely Tobin's $q$ ) corresponding to changes in Chinese firms' corporate governance index values. As firms move from the 'worst' to the 'best' corporate governance practices (and we stop putting these subjective judgements in quotes), they add the extra value of the replacement cost of their assets. By way of illustrating the magnitude of these findings, if all Mainland listed companies moved from worst to best-in-class

\footnotetext{
${ }^{1}$ Tobin's $q$ measures the extent to which companies' market valuations exceed the replacement cost of their assets (roughly speaking). Its plural is probably Tobin's qs (as there is only one Tobin). Yet, the text looks cleaner our way.
} 
corporate governance, such a move would add about $\$ 2.7$ trillion in market capitalization to these firms (see figure for methodology used to find this number). As Cheung and co-authors (2010) show, Mainland firms with better corporate governance list abroad and have higher levels of disclosure (and accompanying levels of market value). Cheung and other co-authors (2007) find that better Mainland corporate governance correlates to higher market valuations for Mainland companies listed in Hong Kong.
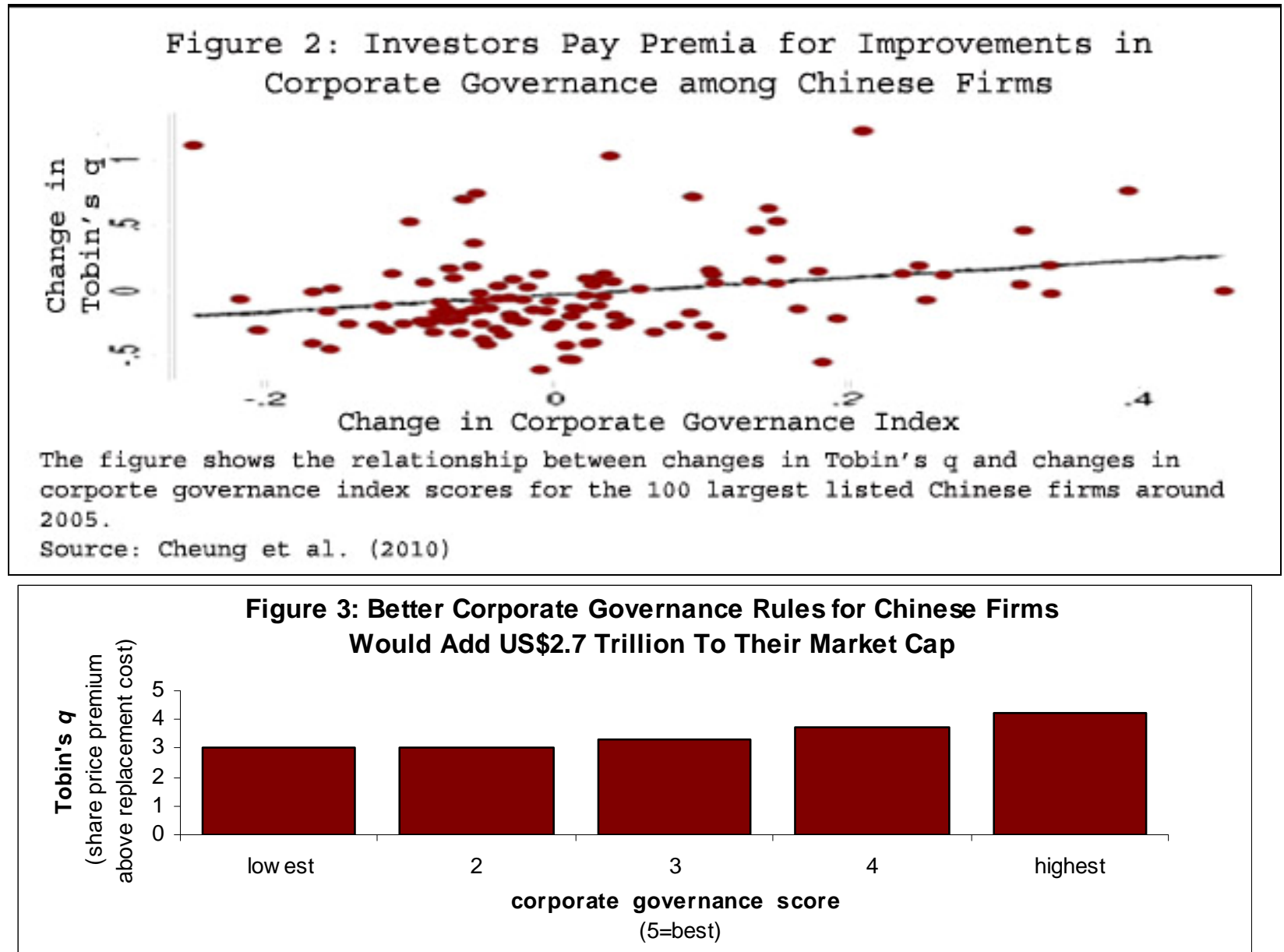

The figure show s the estimated level of Tobin's $q$ corresponding to each corporate governance grade of Chinese companies. Moving from the low est to the highest corporate governance grade w ould increase a Chinese company's market capitalisation by basically one more company (as one more value of the replacement value of the company's assets). The World Bank reports an $\$ 8.2$ trillion market cap for Chinese firms in 2015. If the market values these firms w eigh in at three times their asset replacement cost, and if good corporate governance adds another replacement cost-value, market values should rise by about $\$ 2.7$ trillion.

Source: Based on Bai et al . (2003) methodology and World Bank (2016) for market cap values.

Numerous studies show the types of corporate governance relations correlating with higher market valuations. Figure 4 shows an example from recent studies looking at the econometric relationship between corporate governance and firm performance. After controlling for other variables like market conditions, they find that foreign and institutional ownership, dispersed shareholding, effective boards and audit committees, help lift firm values. Most studies confirm Bai et al.'s (2004) results - market valuations rise when non-controlling shareholders and foreigners hold a large proportion of the company's shares. Market valuations fall with 
concentrated shareholdings, when the CEO also acts as the chairperson of the board, and when government represents the largest shareholder. Even eye-balling the relationship between Tobin's $q$ and corporate governance indices for individual firms shows the positive relationship in studies such as Cheung et al. (2010b). Other authors like Shan and IcIver (2011) find similar evidence for non-listed firms - proving that needed reforms span the Chinese corporate sector. Interestingly, Lin and co-authors (2009) find that the business environment in which Chinese firms compete statistically significantly affects their corporate governance practices. As Chinese firms increasingly list and compete in developed markets, corporate governance practices should improve. $^{2}$

\section{Figure 4: Investors Clearly Pay Premiums for Good Corporate Governance in China}

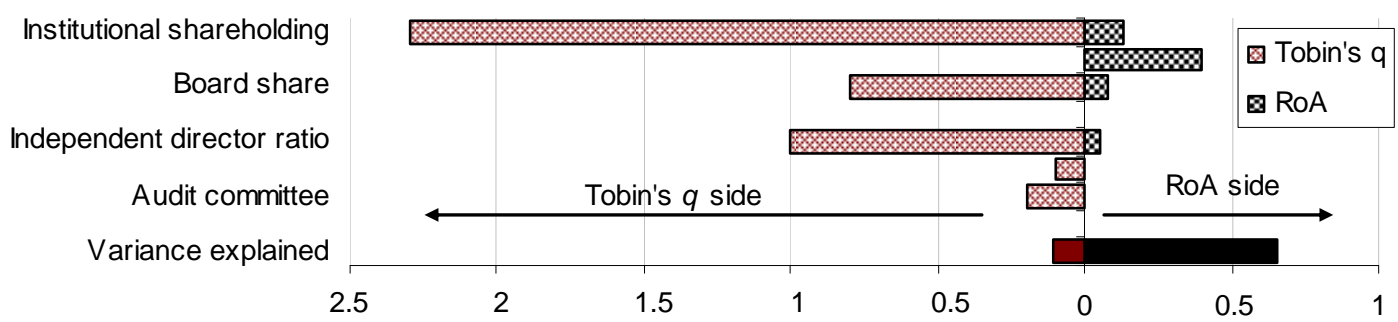

change in performance for 1 standard deviation in each of the indicators show $\mathbf{n}$

(all values positive)

The data show the relationship betw een several indicators related to Chinese firms' corporate governance and their performance (as measured by Tobin's q or market premium over book value) and return on assets. The data show stronger relationships betw een share price mark-ups and corporate governance (after accounting for factors like these firms' asset sizes, leverage and grow th rates) -- than for returns on assets. Yet, models of Tobin's $q$ generally have low explanatory pow er (as represented by the tiny R-squared or variance explained).

Source: Lee and Zhang (2011)

Better corporate governance (as commonly defined) has other advantages which indirectly promote market valuations. ${ }^{3}$ One way consists of helping to reduce the fraud and the self-dealing which makes investors nervous about investing in Mainland shares. ${ }^{4}$ Examples range from Ming Zhao of Puda Coal, ZTE's circumvention of export restrictions to Iran, and the Bank of China's refusal to turn over customer information in a counterfeiting case (Harris, 2016). Academics have quantified the harm such fraud reeks on share prices and demand for Chinese shares. ${ }^{5}$ More specifically, Chen and Zhang (2012) find similarly for the 2002 Chinese Code of Corporate Governance for Listed Companies' effect on earnings manipulation. In their econometric study,

\footnotetext{
${ }^{2}$ The ability to draw on different, well-heeled shareholders represents part of this benefit. Epps and Ismail (2009) show that, for Chinese firms, returns on assets decline with very concentrated and very dispersed shareholding.

${ }^{3}$ We do not repeat the factors that constitute such good corporate governance - like dispersed shareholding, independent directors, etc - to keep our narrative tight. If we must refer to each separate component each time, the text becomes far harder to understand and remember.

${ }^{4}$ The investor-blogger circuit - represented by sites like Kreuzroads (2013) and Chinastockfraud.com (2014) -- has compiled lists of literally hundreds of recent Chinese stock scams. We cite these sites not to suggest that they provide completely reliable information. Yet, the presence of these lists, their popularity and the extent that investors see and believe these lists, point to likely harms in investors' confidence

${ }^{5}$ These harms range from quite a lot to none - with Darrough (2015) representing an example of the first perspective and Lee and co-authors (2015) representing the second perspective.
} 
they find that the Code curbed earnings management by requiring independent non-executive board directors and audit committees staffed with accounting/financial experts. Firth and coauthors (2011) find that the quality of Chinese corporate governance directly affects the "occurrence and detection of financial fraud." Figure 5 shows the effect that corporate governance has on auditor choice - and thus the likelihood of getting away with bad governance behaviour. Lo and colleagues (2010) reach similar conclusions - conducting econometric analysis on transfer price manipulations. As a result, investors needed larger premia to buy shares in companies with poorer corporate governance (Yeh and co-authors, 2009). Thus, better Chinese corporate governance indubitably leads to higher share values.

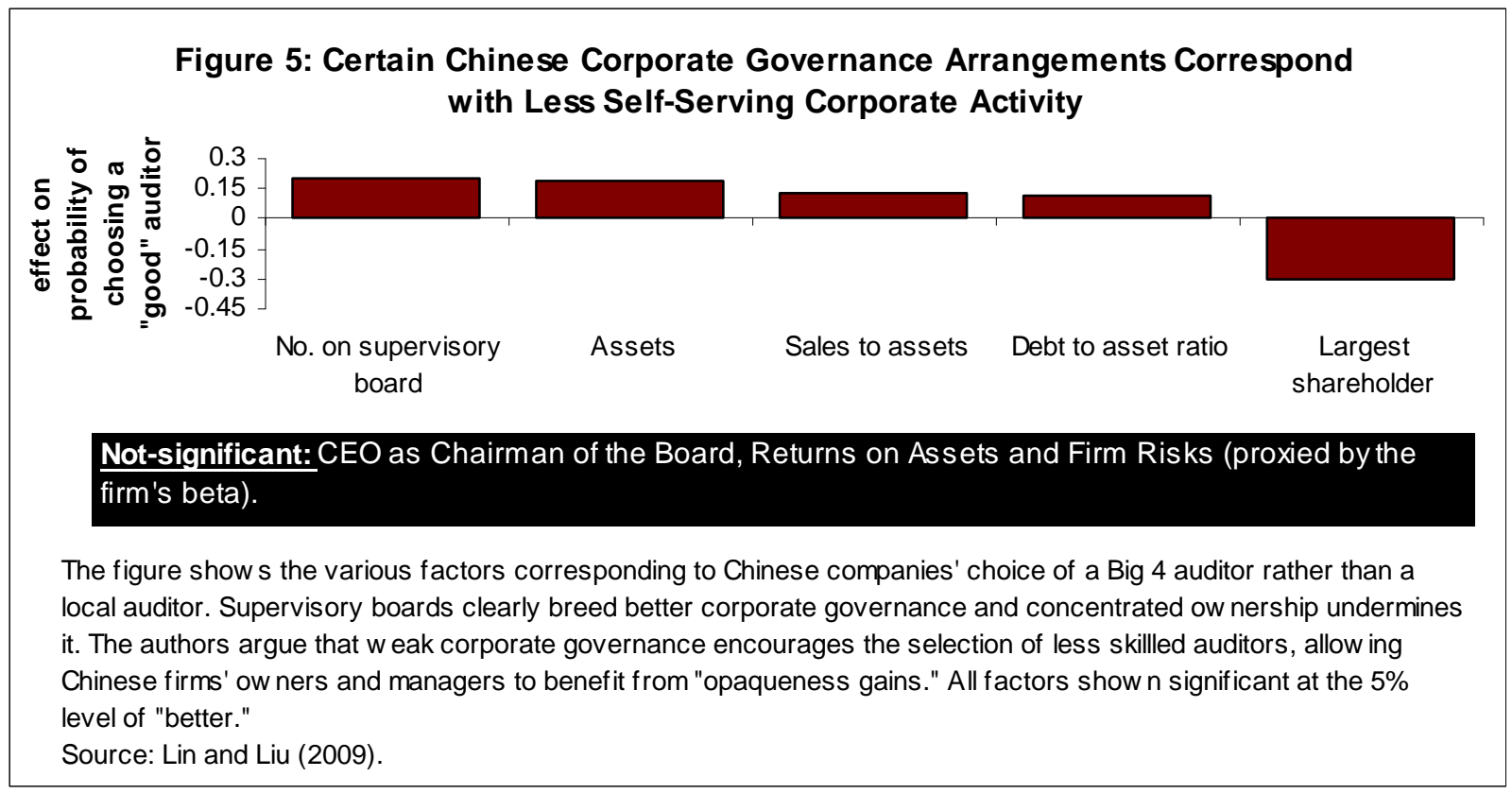

What about simply listing on a foreign exchange? Should/can the Mainland import (or bond) foreign corporate governance to their domestic operations? Guo and co-authors (2013) show that a foreign listing - specifically a Hong Kong listing - can increase the market value of Mainland companies by literally hundreds of percentage points. Other data from authors like Klautzer (2013) show that openness encourages the corporate governance reform that eventually impacts on profits and market valuations. Zhou and co-authors (2011) show that a foreign listing in Hong Kong statistically significantly correlates with increases in Mainland firms' returns on assets, board control, and board characteristics conforming to the corporate governance canon. ${ }^{6}$ Figure 6 shows the estimated premium for Mainland companies earned by listing in Hong Kong (and

\footnotetext{
${ }^{6}$ Specifically "board characteristics" consists of proxies for the presence of foreign directors, the Board's international experience, the establishment of professional committees, board size, number of boards, proportion of independent directors, separation of chairman from general manager, and annual chairman changes. "Board control behavior" consists of attendance rates of independent directors, overall board attendance, independent directors' objections, rate of independent directors, performance review of the board, stock incentive mechanisms, the number of shareholders at general meetings, the number of extraordinary shareholder meetings, disclosure of business goals/ conditions and vision, the implementation of board resolutions, professionalism of committees' reports, number of institutional investors, and the equity ratio of the company's first major shareholders. See source for more details on the construction of these variables.
} 
thus theoretically complying with the Hong Kong Stock Exchange's Code of Corporate Governance. Certain companies -- like Northeast Electric Development, Jilin Chemical Industrial, and Shandong Xinhua Pharma - saw very large increases in their share premia.

\section{Figure 6: Misleading Examples of Price Premia Earned by Listing in Hong Kong Rather than the Mainland}

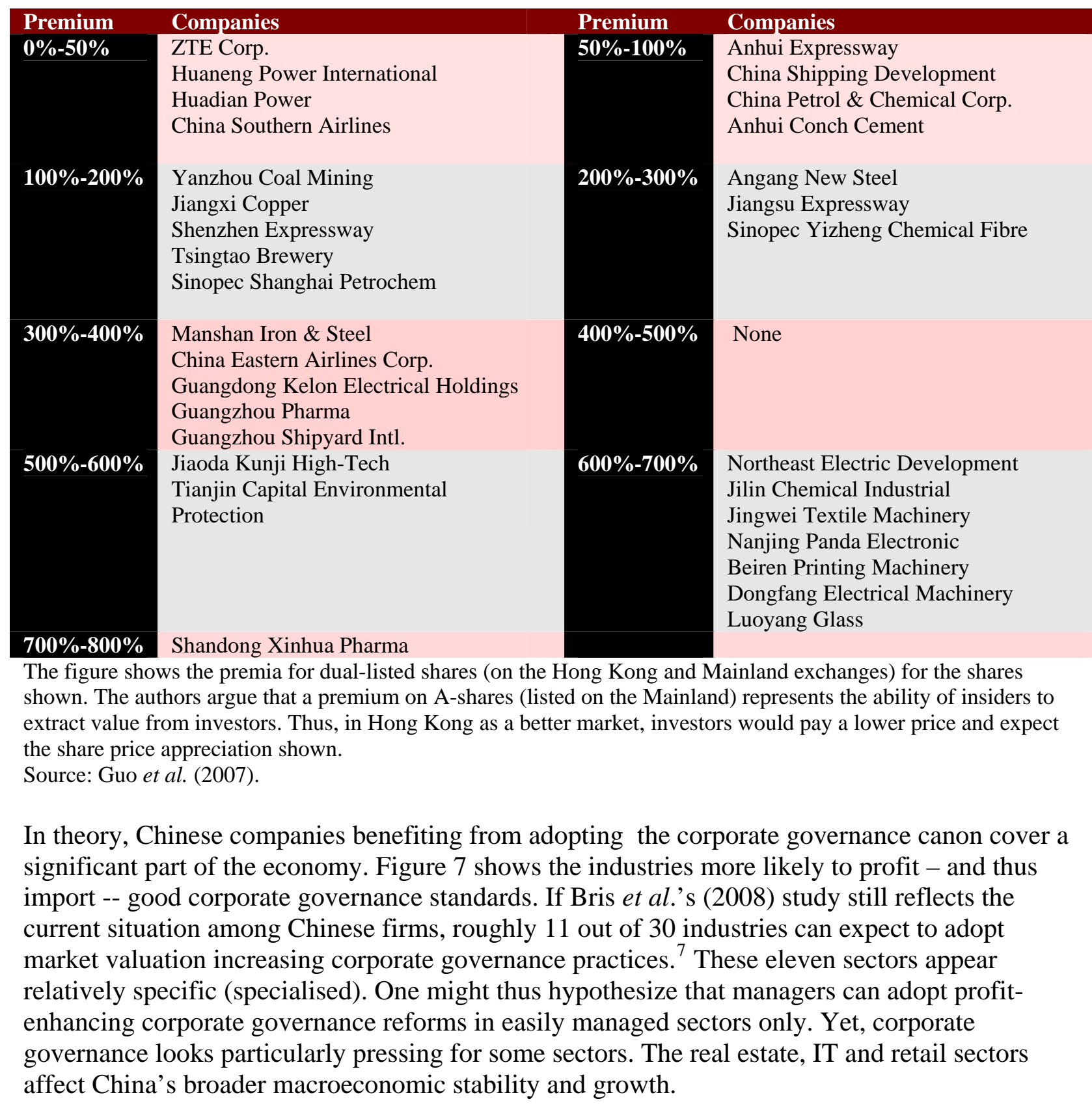

\footnotetext{
${ }^{7}$ The situation may not hold, as these sectors might have already adopted all the corporate governance reform they can.
} 
Figure 7: Sectors Where Importing Corporate Governance Standards Has Affected Tobin's $q$ for Chinese Firms in the Past

$\begin{array}{lll}\text { Effect } & \text { No effect } & \\ \text { Construction } & \text { Autos } & \text { IT } \\ \text { Healthcare } & \text { Beverages } & \text { Leisure goods } \\ \text { Steel } & \text { Electricity, water, gas } & \text { Mining } \\ \text { Pharma and biotech } & \text { Engineering } & \text { Oil and gas } \\ \text { Media } & \text { Food and drug retailers } & \text { Personal goods } \\ \text { Specialty finance } & \text { Food producers } & \text { Real estate } \\ \text { Mobile telecom } & \text { Forestry \& paper } & \text { Retail } \\ \text { Tobacco } & \text { Household goods } & \text { Software and computer } \\ \text { Travel/leisure } & & \text { Support services } \\ \text { Diversified Industrials } & & \text { Water } \\ \text { Electronics } & & \end{array}$

The figure shows the industries for which Tobin's q statistically significantly changed due to differences in shareholder protection or accounting standards between China and another jurisdiction from which target firms hail during an M\&A. The authors argue that importing corporate governance policies and practices causes these changes in market valuations.

Source: Bris et al. (2008) at table 8.

Yet, we do not seem to know why. Few studies find evidence of "bonding” (or Chinese firms adopting corporate governance standards when they list and work abroad). Dong and Xue (2009) test the extent of such bonding, looking at the extent to which corporate governance related variables (like board size, compensation and other factors) statistically significant differ between Chinese firms listed in Shanghai/Shenzhen, in Hong Kong or in New York. They find some factors, like the salaries of the top three board members, and local demand conditions, and all kinds of public disclosure statistically significant differ for firms choosing to list on different exchanges (Ibid, Table 3). Yet, factors like board sizes or the proportion of independent directors do not differ - putting into doubt the extent of such bonding. Authors like Clarke (2015) write even more sceptically about bonding. He argues moreover that whether Chinese firms "bond" to foreign corporate governance requirements and values, such rules would not protect investors any more than rules at home in China. Consequently, any share price premium paid by investors comes from their misplaced belief in the likely success of legal action should these Mainland listed companies run into difficulties. Grove and Clouse (2013) might agree - citing Longtop Financial Technologies, China MediaExpress, Harbin Electric, China-Biotics and Deer Consumer Products as companies delisted in New York for fraud. ${ }^{8}$ Simply listing on a foreign exchange like Hong Kong's should not, in itself, provide sufficient impetus for improving (importing) better corporate governance practices on the Mainland.

Maybe only the indirect effects of better corporate governance rules help improve market discipline - and thus owners'/managers' incentives to maximise shareholder value? We have shown above that better corporate governance's direct effects do not seem to improve shareholder value. What about corporate governance’s indirect effects - encouraging transparency and

\footnotetext{
${ }^{8}$ Lee and colleagues (2014) dispute these claims, particularly in relation to Chinese reverse mergers (backdoor listings) into the US. They note that even after accounting for fraudulent firms, these companies do better as a group than their US peers.
} 
disclosure needed for investors to price and trade Chinese firms' shares accurately? ${ }^{9}$ If Hong Kong's corporate governance rules reduce information asymmetries between investors and insiders, share prices should better reflect such firm-specific information. ${ }^{10}$ Yet, Figure 8 very much casts doubts on the extent to which better corporate governance leads to more informative share prices (which reflect firm-specific, rather than general market-related, news). Hong Kong share turn-over of Mainland companies does increase, relative to Mainland share turnover for cross-listed shares, in response to firm-specific events (news). Yet, adoption of the practices usually considered as part of good corporate governance fail to make share prices in Hong Kong more responsive to firm-specific news. Such irrelevant factors include institutional ownership, independent directors, and even lack of shareholder concentration. Simply listing in Hong Kong does not guarantee that Mainland companies receive the benefits of (or discipline from) better corporate governance.
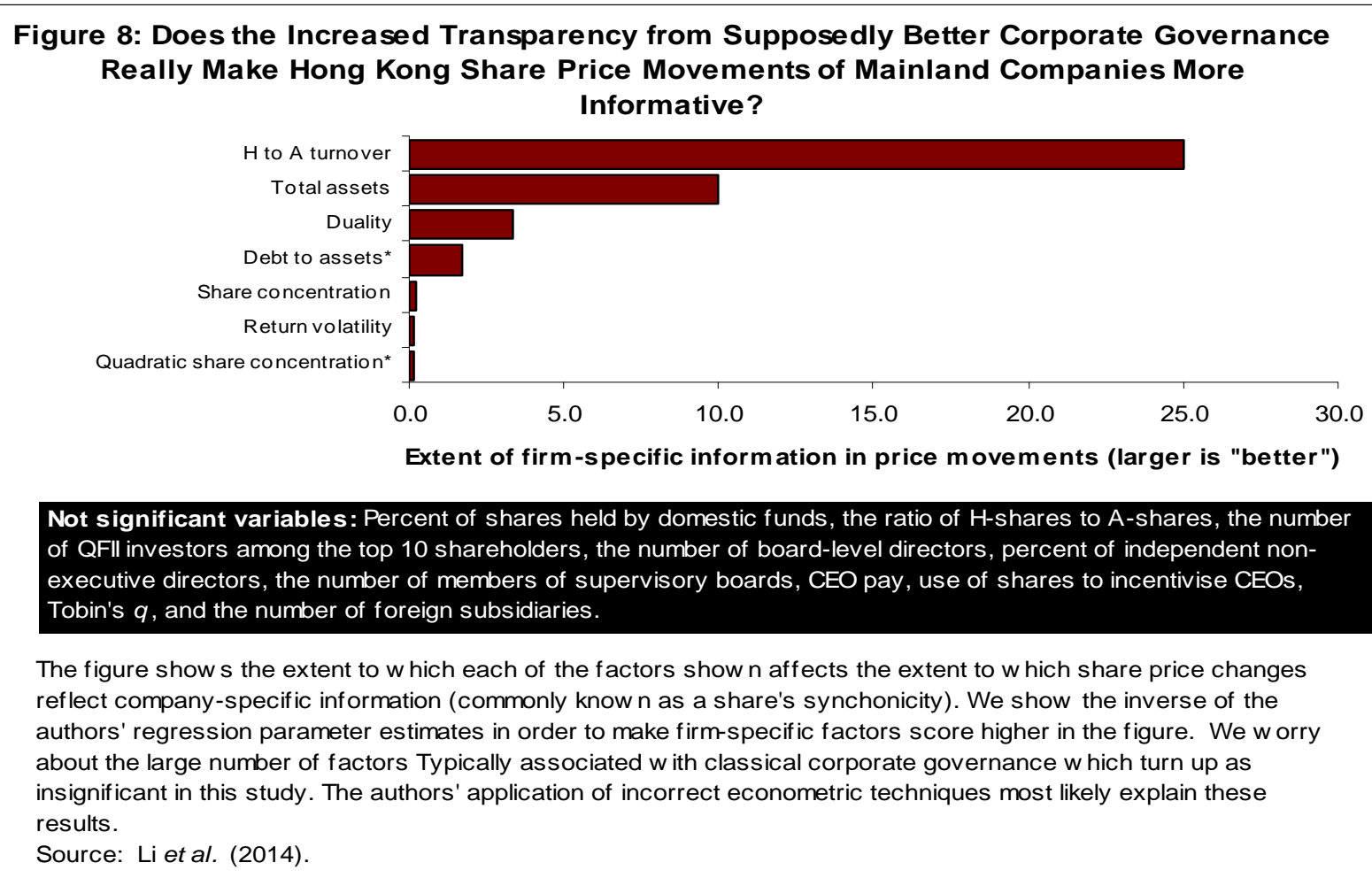
reflect company-specific information (commonly know $\mathrm{n}$ as a share's synchonicity). We show the inverse of the authors' regression parameter estimates in order to make firm-specific factors score higher in the figure. We w orry about the large number of factors Typically associated with classical corporate governance $w$ hich turn up as insignificant in this study. The authors' application of incorrect econometric techniques most likely explain these results.

Source: Li et al. (2014).

The recent bout of Mainland company fraud involving foreign listings as well as domestically listed firms strongly suggests that foreign listings, and their supposedly stricter corporate governance rules, do not lead to better governed Mainland firms. ${ }^{11}$ Figure 9 shows how fraud has

\footnotetext{
${ }^{9}$ In this context, “accurately” refers to investors' ability to observe information signalling likely mismanagement, self-dealing, and other problems.

${ }^{10}$ As in the previous sentence, we do not explicitly define our terms (in this case "information asymmetry") as managers and owners knowing about their own self-serving, neglect, fraud or even excessive risks which investors can not properly value. Without abandoning our scientific precision, we can not accurately describe every concept in several sentence. Otherwise, readers would be unable to read such dense and long-winded writing.

${ }^{11}$ We talked above about the effect of fraud in general. We now focus on their effect specifically on foreign listing as the topic of this part of this paper and as a led-in to the next section.
} 
significantly reduced market valuations of Mainland shares listed abroad - as reflected in several FTSE (2016) indices. Shares of Chinese companies listed on the Mainland (A shares in particular) have yielded positive returns since 2011. Yet, a recent correction has shown that these previous gains did not reflect knowledge about frauds going on at the time ( $\mathrm{Yu}, 2016)$. The prices of Mainland shares listed and traded in the US - and particularly Singapore -- have seen the largest declines. ${ }^{12}$ High levels of demand in Hong Kong for Chinese shares explain why share prices have not fallen as rapidly on the Hong Kong bourse. Fraud contributed to the large sell-off of securities in the US - with about 1/3 of all Chinese companies listed in the US had financial scandals. ${ }^{13}$ Indeed, the lower part of Figure 9 shows that the sell-off centred on small cap shares (whose companies have the weakest corporate governance) the heaviest. Some Mainland companies look toward listing “transfers.” These transfers entail Chinese companies' delisting in the US or other foreign markets in order to relist at home in China (Gu, 2016). Some companies probably seek to cash-in on the fraud and run away before news of such fraud catches up with their share prices. Others seek to avoid the extra scrutiny. Yet, these companies will not represent the bulk which try to maximise profits over the longer term - many by adopting the corporate governance canon.

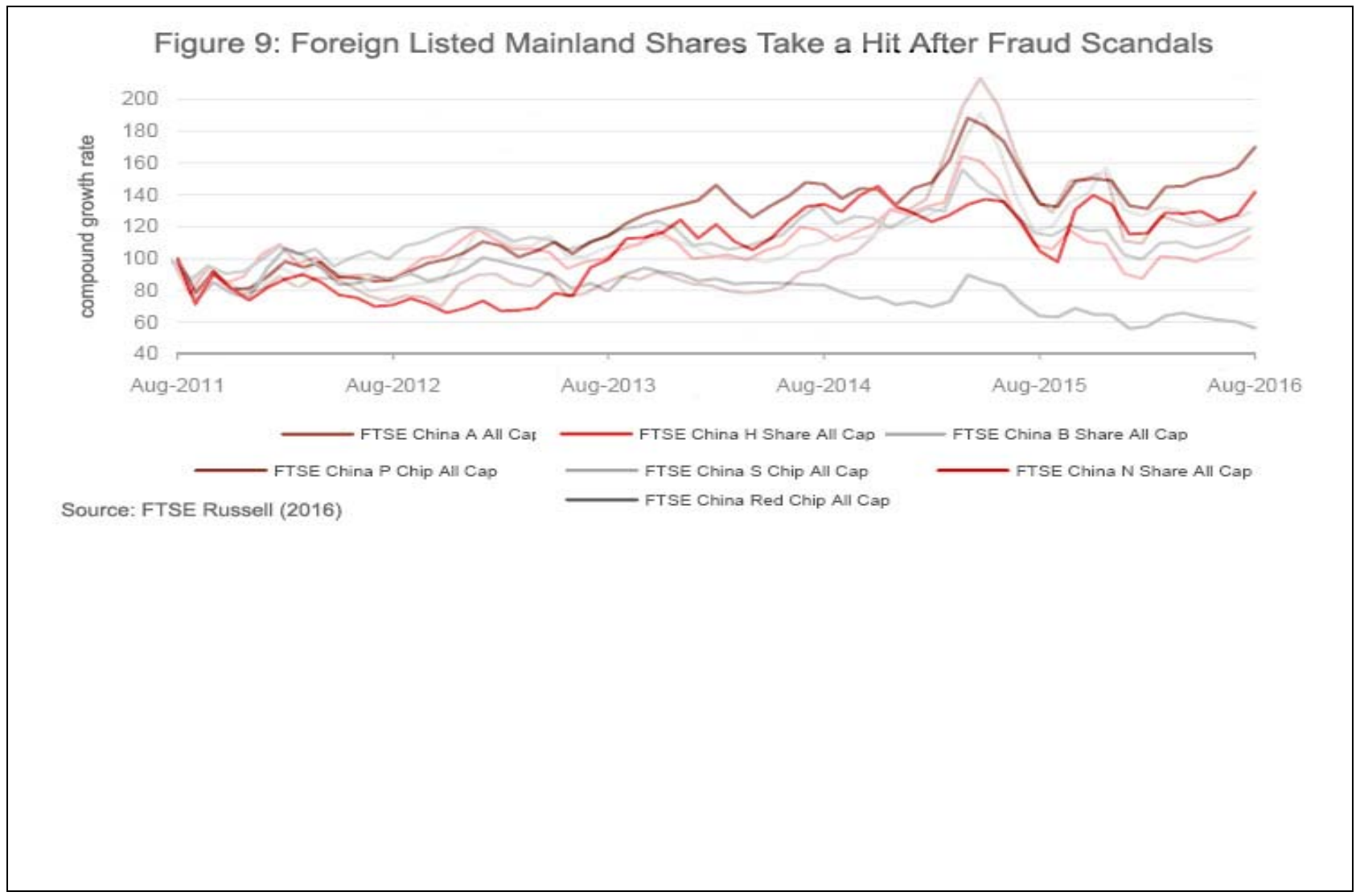

${ }^{12}$ S-shares receive very little analysis in the English language press and among English-language academics. Thus, we can not speculate about the reasons for the S-share's price changes in Singapore.

${ }^{13}$ Beatty and co-authors (2013) provide a superlative account of these frauds as well as related econometric analysis. Ang and co-authors provide the 1/3 figure, and other in-depth facts about these frauds. 


\section{The Effect of "Importing” Corporate Governance Rules}

What does the experience of Chinese companies, which have actually improved their corporate governance while listed in the US (and other countries), tell us about the corporate governance's effects on profits and returns? Figure 10 shows the effect of the Sarbanes-Oxley Act on the market premia of various types of firms. ${ }^{14}$ The positive effects on foreign firms seem to exceed those of all firms analysed as a single group. Only small foreign firms seem to gain less market valuation relative to large foreign firms - an effect we already saw in the case of Mainland listings (due to fraud risk). How did particular aspects of these firms' corporate governance influence the excess returns accruing to these firms after the adoption of the Sarbanes-Oxley Act? The figure also shows that, for the whole lot of firms, factors like having an independent nominating committee, independent audit committee, having a CEO which does not serve as chairperson, low inside share ownership, high institutional share ownership, low audit fees as share of total assets, and low market capitalisation all lead to large post-Sarbanes Oxley effects on extra (abnormal) returns. Yet, among foreign firms, only the corporate governance factor of having an independent nominating committee seemed to boost these excess returns. These results thus suggest that corporate governance regulatory reform would likely help even those Chinese companies that have not embarked on their own corporate governance reforms. ${ }^{15}$

\footnotetext{
${ }^{14}$ The authors obviously made some mistake in their calculations, as the standard deviations they report for the statistically significant results which we cite here exceed the mean values by a factor of 10 . We assume the authors rescaled the data and forgot to report the rescaling.

${ }^{15}$ This conclusion's logic is as follows. Having these various corporate governance attributes does not affect the Sarbanes-Oxley Act's effect on excess market returns. Yet, we see that these returns clearly increased for foreign firms. Thus, some combination of these reforms contributes to these excess returns (or completely outside factors account for these returns). Yet, coming from different jurisdictions, industries and so forth, these firms do not have common factors affecting them which might point to non-corporate governance related effects.
} 


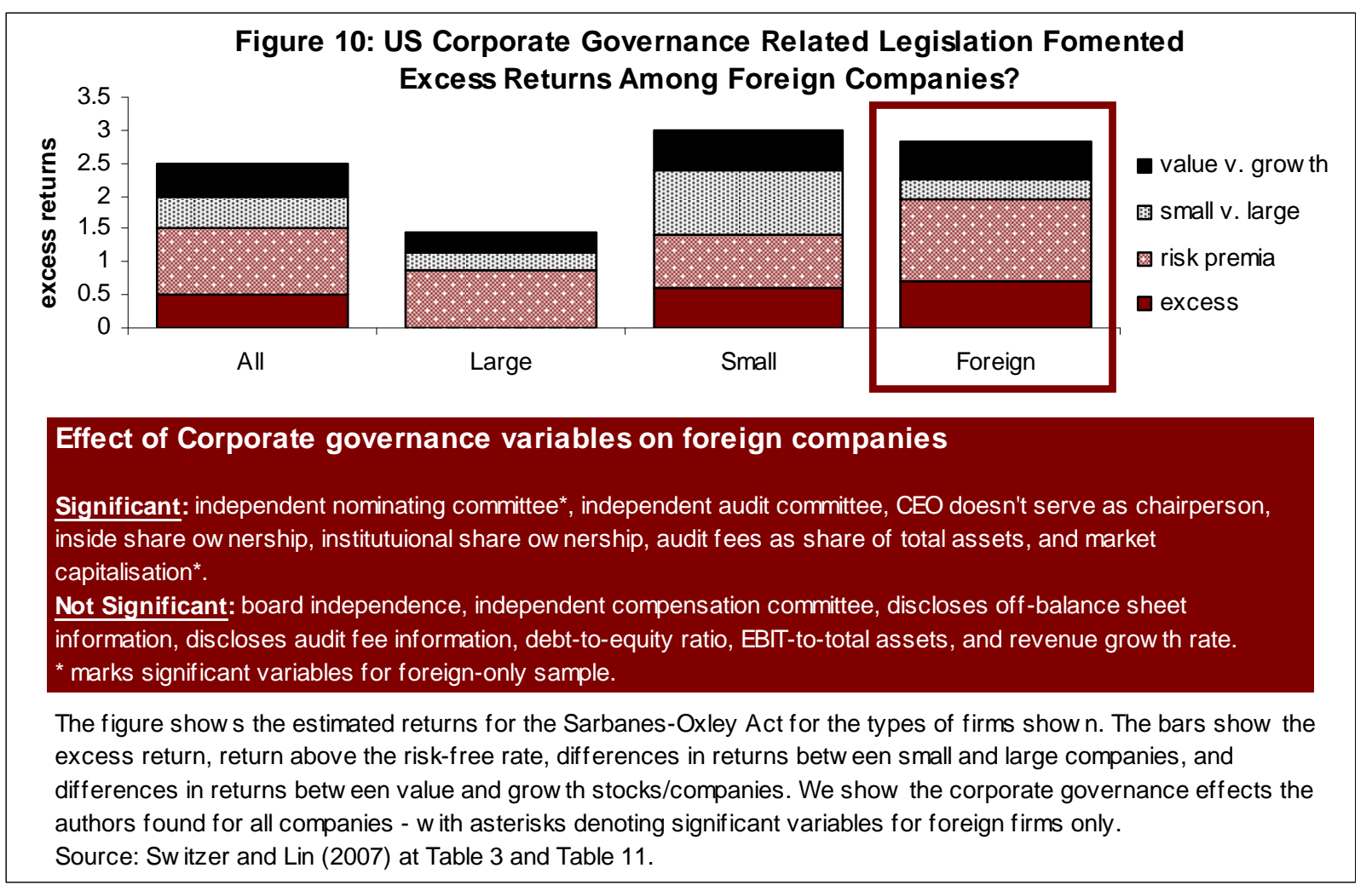

Other data seem to support the view that stronger corporate governance regulations could benefit Mainland (and other foreign) firms. Figure 11 shows the gain in abnormal returns and decreased delistings for non-US firms listed in the US as a result of the adoption of the Sarbanes-Oxley Act. ${ }^{16}$ In summary, the authors find that foreign companies listed in the US most benefited from Sarbanes-Oxley when they come from jurisdictions with moderate accounting standards and shareholder protection. To put their findings colloquially, foreign firms "bond" (adapt more stringent corporate governance policies) when coming from jurisdictions with Goldilocks corporate governance -- not too bad and not too good. ${ }^{17}$ Looking specifically at the way Sarbanes-Oxley impacted on company risks, Litvak (2014) finds that a similar Goldilocks phenomenon. High risk foreign firms' risks fell after the adoption of Sarbanes-Oxley. However, their market valuations also fell. Only large companies from poorer jurisdictions complied with the Act - whereas all companies seemed to comply from other jurisdictions. These result thus point to a kind of reform momentum, whose history makes clear the reasons and targets of such reform (Zhang, 2014). Once Chinese (and other foreign) firms start their corporate governance reform, such reform creates the impetus for more reform - facilitating further reforms (Peng and Blevins, 2014).

\footnotetext{
${ }^{16}$ Technically, the study looked at these variables before and after the adoption of the Act. We follow the authors' language trying to tie such a correlation to causality.

${ }^{17}$ To take one example, Amoako-Adu and Baulkaran (2007) show how Canadian firms listed in the US lost market value de to the implementation of Sarbanes-Oxley.
} 


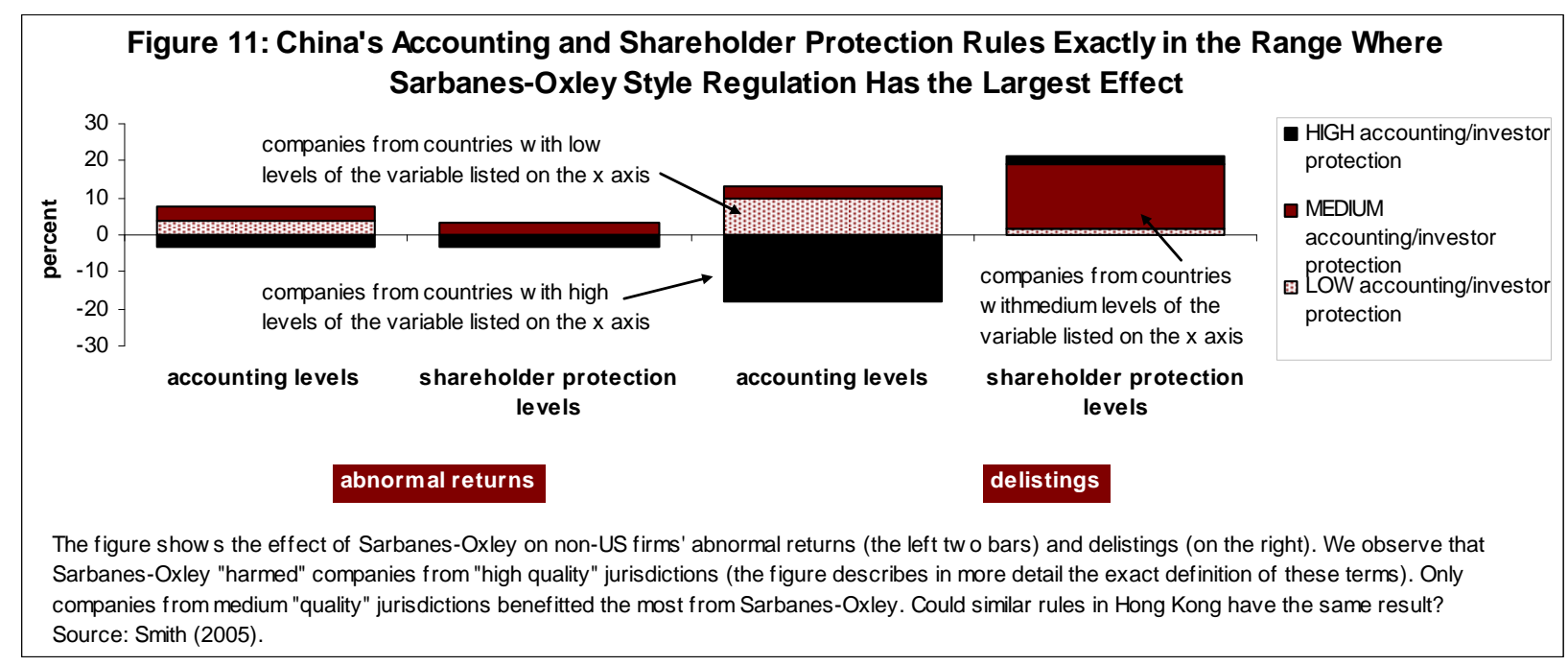

Not to belabour the point, but other evidence suggests that adopting the corporate governance canon would even help improve corporate governance in the areas these companies are based in and work in. Figure 12 shows the relationship between the percent of Chinese companies listing abroad from a particular Chinese city or region and the quality of local institutions in that area. Just by eye-balling the data, we can see that more companies from places with higher institutional quality list abroad more often. Thus these companies can, and do, conform with these foreign exchanges' more stringent corporate governance rules. Yet, within each grouping of places (by institutional quality), we see that Chinese firms from places with worse lower institutions (relative to similar regions) tend to list abroad more often. ${ }^{18}$ Such a propensity suggests that Mainland firms use foreign listings as a way to import standards needed to compete with peers who work in better institutional environments. The canon helps improve the governance environment as much "around" the company (in its stakeholder entities) as in the company.

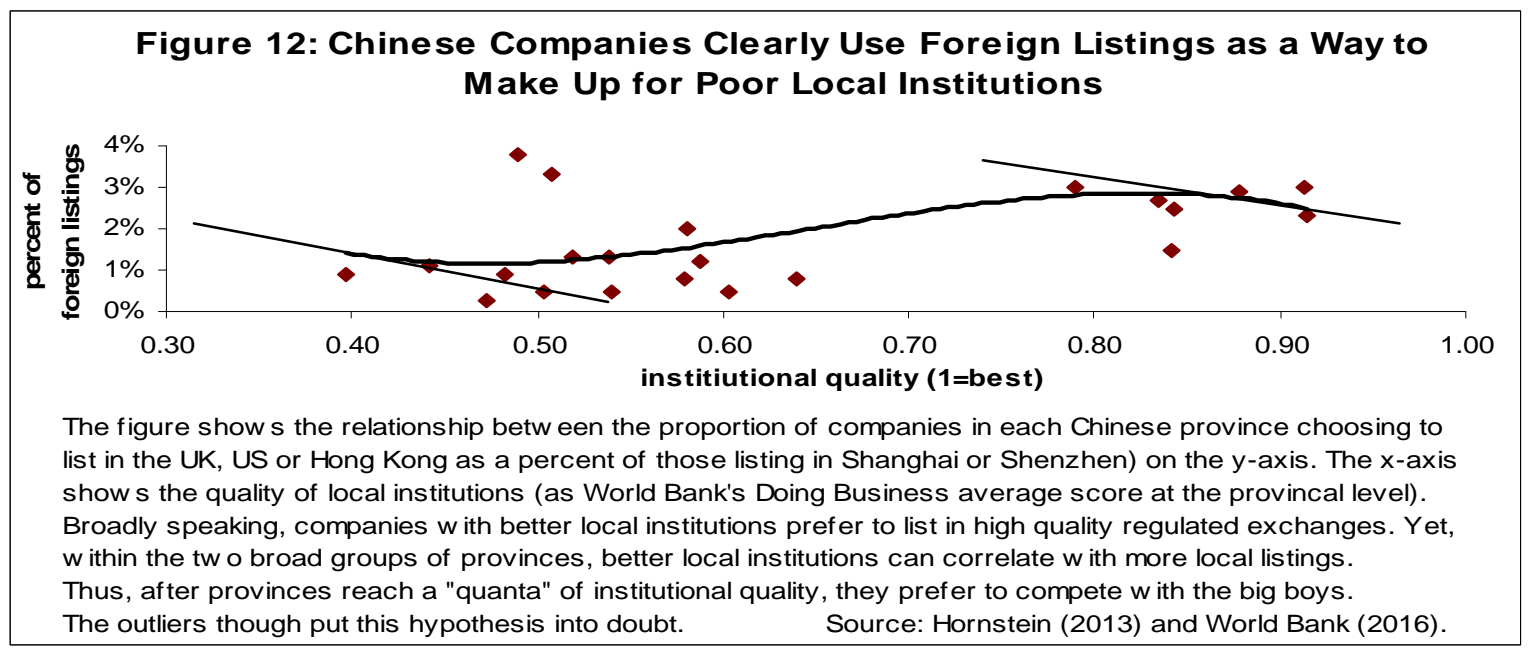

\footnotetext{
${ }^{18}$ In order to keep this paper readable, we do not yet again provide the definition of institutions (or institutional quality). Readers should see the original study for more details.
} 
Regulations requiring greater disclosure not only benefit the companies themselves, but also the business environment in which they work. ${ }^{19}$ Authors like Laurence (2013) find that both individual and institutional investors actually do trade on the information disclosed. Chen et al. (2014) go further, looking at the extent to which poor disclosure and other corporate governance practices correlate with mis-investment (namely under or over investment as assessed by past, present and future revenues). As shown in Figure 13, alone, disclosure does not have a statistically significant effect on over or under-investment. Yet, disclosure does affect Mainland companies' corporate governance - which in turn affects investment. ${ }^{20}$ Increased disclosure when combined with better corporate governance seems to reduce over-investment - if increasing under-investment. Looking at the effects in well-governed Chinese firms shows a total decrease in investment inefficiency (namely the extent to which these firms over or under-invest). Market characteristics seem to have only microscopic effects on the extent of disclosure. Firms will disclose more before attracting external finance and when returns to assets rise. Disclosure decreases when market valuations increase and when a firm's management has more political connections.

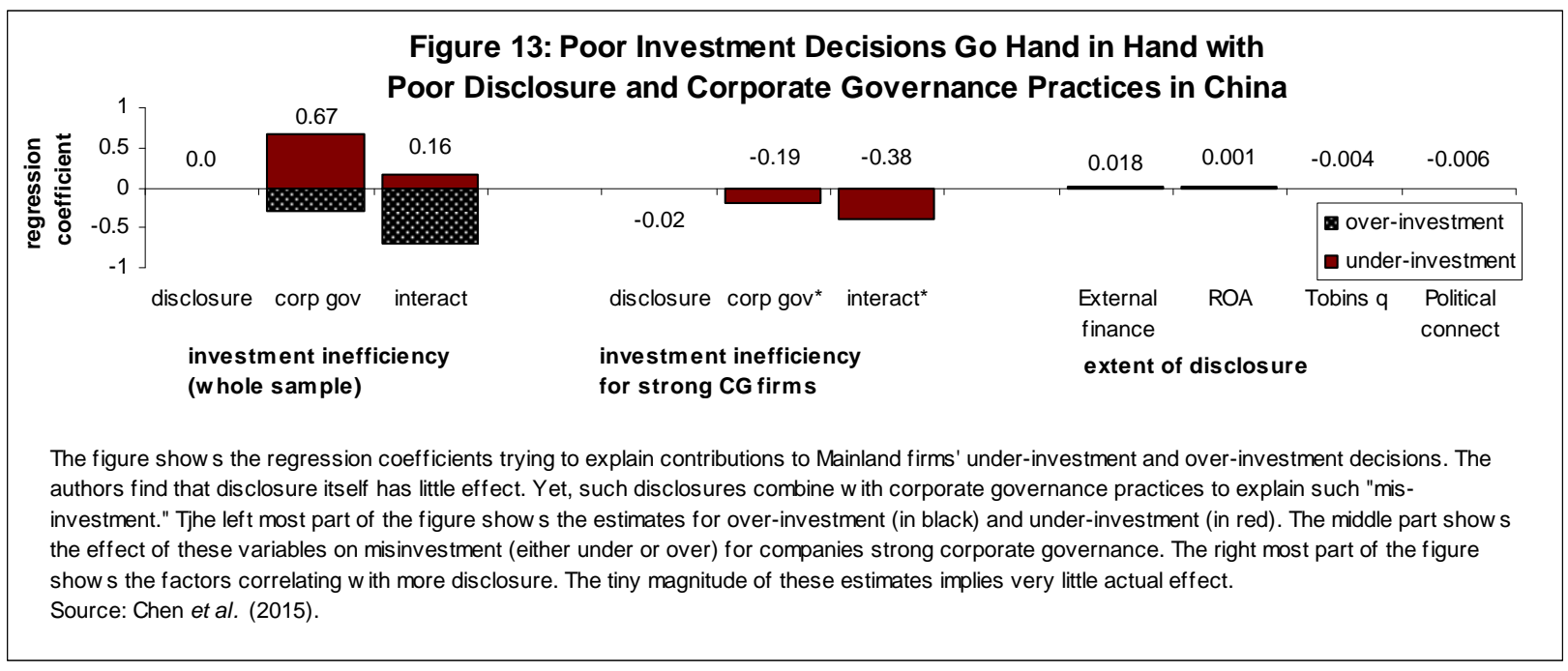

Stronger Hong Kong rules on disclosure could encourage Mainland firms to engage more profitable disclosure. Figure 14 shows the disclosure-producing effects of a foreign listing on Mainland firms. Market valuations rise when Mainland companies disclose abroad - presumably because foreign investors and stakeholders can act more effectively on these disclosures than those inside China. Probabilities of increased disclosure (including voluntary disclosure) jump very significantly when these Mainland firms list overseas. For authors like Xi and Yang (2016), increased disclosure builds constituencies for further disclosure - as the earnings quality improves as well as shareholder/analyst demand for disclosures increase. For authors like Myers and Steckman (2014), increased transparency and disclosure serve to make Mainland corporate

\footnotetext{
${ }^{19}$ Choudhury (2016) in particular provides a balanced discussion of the legal issues involved in adopting such disclosure rules.

${ }^{20}$ The joint effect (ie interaction) between disclosure and corporate governance yields positive effects on underinvestment and negative effects on over-investment. One interpretation of these data might argue that such disclosure seems to cause boards to act more conservatively than otherwise.
} 
governance more self-enforcing. Thus, once such disclosure gains momentum in a place like Hong Kong, further transparency looks more likely.

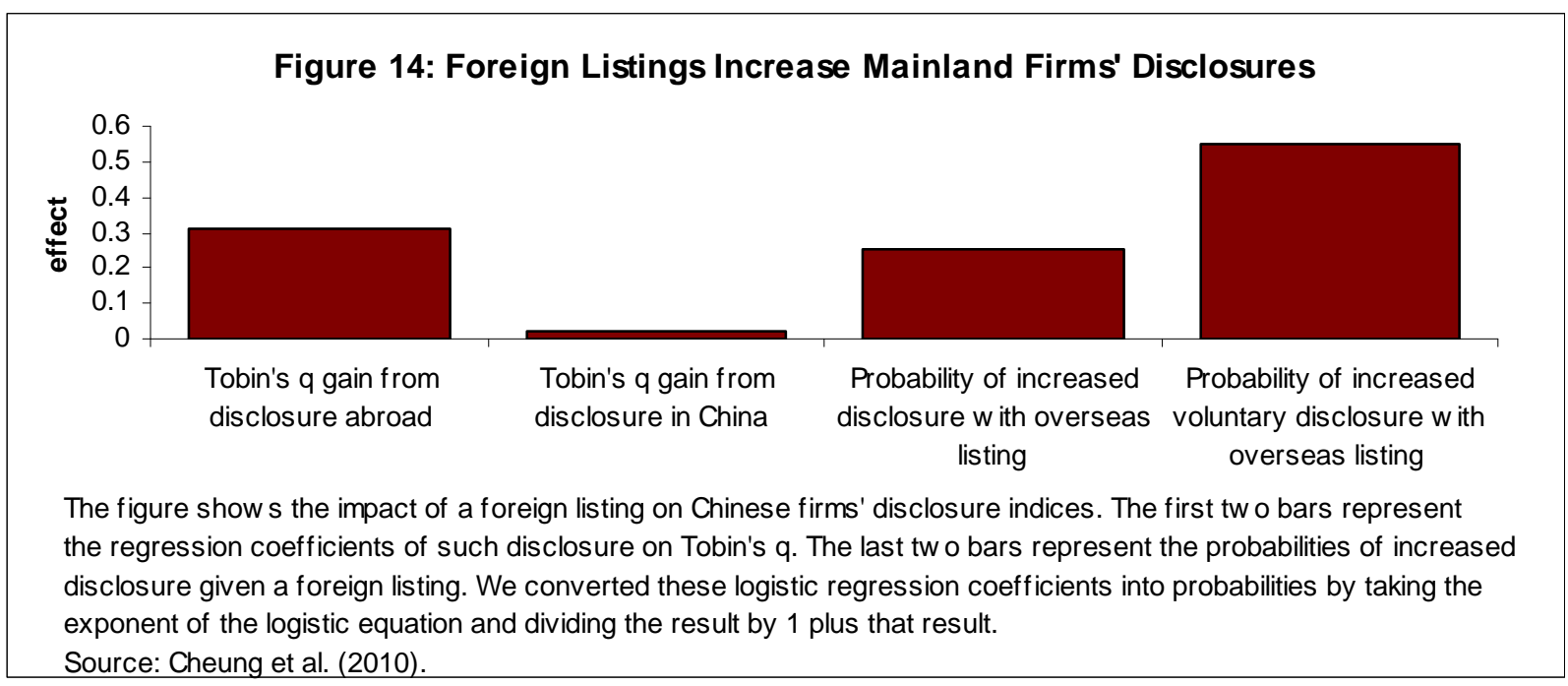

What kinds of gains can Mainland firms expect if they adopt the corporate governance canon (as embodied by rules like those required by Hong Kong's Stock Exchange? If Sarbanes-Oxley Act serves as any guide, Mainland firms could lower their capital costs by $0.7 \%$ to $1 \%$ (Hail and Leuz, 2008). Piotroski and Srinivasan (2008) find that Sarbanes-Oxley did not distort foreigners' incentives to list on foreign markets. ${ }^{21}$ Instead, worse governed companies had to delist (or face the extra compliance costs) - thereby improving market quality and shareholder protection for all listed companies. ${ }^{22}$ Of course, as Wintoki (2007) and Grinstein \& Chhaochharia (2007) show, not all companies - and especially small firms -- should have the same stringent corporate governance requirements. Engel et al. (2007), using relatively old data whose conclusions still apply to today's situation, find that companies with more insider (managers'/directors') shareholding delisted much more than those with more dispersed shareholding. They further find that the abnormal returns to insider controlled companies which delisted around the time of the Sarbanes-Oxley Act's adoption exceeded those of their control group by $6 \% .{ }^{23}$ Evidence from Belgium shows that the Act had the effect of actually the improving corporate governance of US listed overseas companies - by causing decreases in earnings management, and thus likely other kinds of accounting manipulation (Dutillieux and Willenkens, 2009). As such, it looks like stricter corporate governance rules improve investment returns, even if these policies decrease the discretionary influence of insider managers and directors. But we just do not know... and we spent 15 pages proving it.

\footnotetext{
${ }^{21}$ Economists care about relative distortions in a market more than the size of the market - as pure changes in size only affect marginal incentives (and do not change the distribution of resources or investment decisions.

${ }^{22}$ Hostak and his co-authors (2013) represent one of the many other studies to confirm these findings.

${ }^{23}$ We calculated this statistic by taking the differences-in-differences of pre and post Sarbanes Oxley data and of delisters from control group companies (as reported in Table 7).
} 


\section{Effects of Corporate Governance Changes on Hong Kong Listed Chinese Firms}

What effect would adopting the corporate governance canon - represented by Hong Kong's better corporate governance policies and practices -- have on foreign and particularly Mainland firms? Hong Kong-listed Mainland companies' share price changes might provide some clue. The last major revisions to Hong Kong's code of corporate governance occurred in $2011 .{ }^{24}$ The easiest way of guessing what the effects the revision of Hong Kong's code of corporate governance on Mainland firms had consists of looking at the differences-in-differences of their share prices (as described in detail in the Appendix). Namely, we looked at the difference in share prices for Mainland firms listed in Hong Kong from January 2011 to December 2012. Share prices from for Hong Kong firms listed on the Hong Kong stock market increased on average by $20 \%$ at a time when Mainland shares on the Hong Kong stock market fell by $11 \% .{ }^{25}$ The $11 \%$ fall in Mainland companies' shares listed on the Hong Kong stock market partly explains that drop in the overall market index. Yet, such a drop pales in comparison to the $33 \%$ drop in the overall Mainland share price index (World Bank, 2016b) ${ }^{26}$ The difference between Hong Kong and Mainland firms' difference in share prices from the beginning of 2011 to the end of 2012 thus comes to around 31\%. Such a difference comes from the company-specific and policy-specific differences between Hong Kong and Mainland firms. Mainland firms listing in Hong Kong thus saved 22\% in losses - an effect we might call a Hong Kong listing effect. At that same time, Mainland firms experienced the changing corporate governance rules at a time when other companies around the world did not. These other companies share prices in the global S\&P index fell by $15 \%$. Thus, the specific effect of the corporate governance changes on Mainland firms - after removing market specific effects - comes to 7\%. If the differences-indifferences methodology removed other effects, revisions to Hong Kong's code of corporate governance should have cased a 7\% lift in Mainland share prices.

Extending on this logic, we can derive the value of corporate governance reforms on Mainland companies' market capitalisation. As we reported earlier, Mainland firms had a market capitalization of $\$ 8.2$ trillion and better corporate governance has the potential to add another $7 \%$ in share value. We can not know the extent to which the Mainland government's own efforts at corporate governance reform will increase share price valuations. If we assume that existing and planned corporate governance reform on the Mainland will translate into increases in market value of 3\%, then the remaining 4\% increase (times 8.2 trillion) equals roughly $\$ 330$ billion. Thus, radical changes to Hong Kong's corporate governance rules could increase market capitalizations on the Mainland by around $\$ 330$ billion by the time their effects work through these companies.

Changes to corporate governance rules would also affect these firms' riskiness and the distribution of share price gains between Mainland firms. Figure 15 shows the spread in share prices for Hong Kong listed firms' share prices in 2011 and in 2013. We have matched these

\footnotetext{
${ }^{24}$ The HKICPA (2012) provides the background and content of that reform. As noted by the Hong Kong Exchange (2010), the Exchange started consultations on reforming the corporate governance code in 2010, with implementation carrying on in 2012.

${ }^{25}$ Such an increase occurred against the backdrop of a 5.4\% drop in the S\&P Global Market Index tracking Hong Kong (as reported by the World Bank, 2016).

${ }^{26}$ As we only want ball-park estimates for this paper, we do not disaggregate the Chinese markets into specific exchanges - like the Shanghai or Shenzhen exchanges.
} 
price distributions to the closest fitting statistical distribution for these price changes (a log logistic curve). As shown, share prices between listed firms tightened after the code of corporate governance revisions. Such share price convergence should not surprise us -- as the expanded and standardized corporate governance regulations probably had the effect of reducing the variability of firm-specific differences in the governance practices which reflected on their share prices. Figure 16 though shows the dark side of such reforms. Compared with share price changes around the world, the share prices of many Mainland firms listed in Hong Kong dropped significantly. If we fit the tightest statistical distribution possible on the data, the resulting average price drop came out to around $20 \%$ more than world equity prices fell. Yet, when we take into account the larger share price gains of some companies (by fitting a normal distribution to the data), overall share prices rose by $7 \%$. These data confirm a trend repeated by so many corporate governance researchers. Corporate governance reform may increase share price values in the longer-run, even if many companies lose in the short-run. ${ }^{27}$

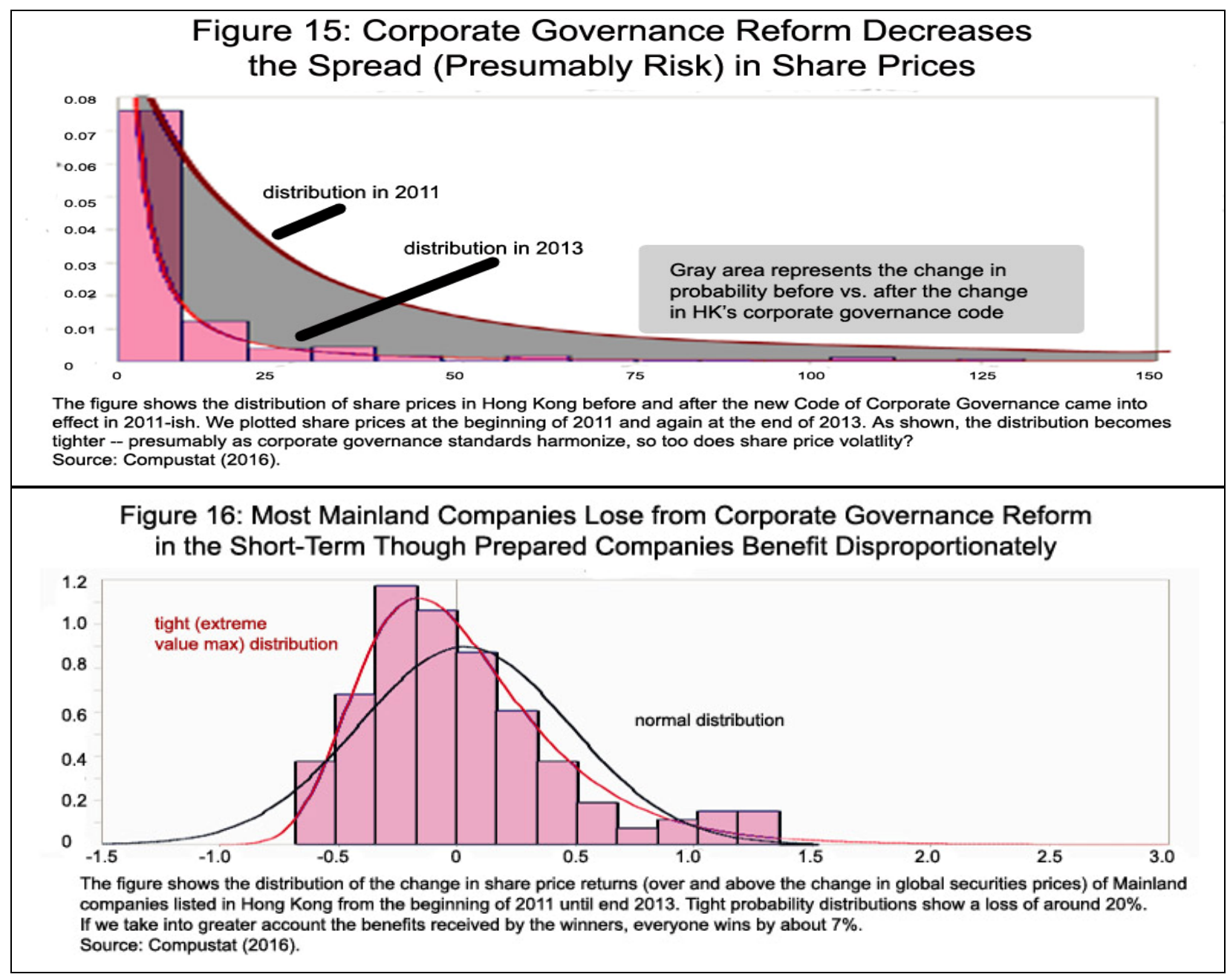

${ }^{27}$ Claessens (2006) as well as Black and co-authors (2008) might explain such dynamics due to short-term resistance by the entrenched owners and managers whose interests corporate governance reform may threaten. Indeed, commentators like Crawford (2009) note that corporate governance reform's whole purpose consists of getting managers to focus on the longer-term. 
Naturally, any one using these simple estimates should use a bit of common sense. These results capture any Hong Kong-specific effect...not just the effect of its corporate governance and corporate governance rules. The size of equity available, slight differences in rules like shorting shares, and even cultural factors may account for some of this $7 \%$. Yet, given investors' ability to arbitrate these differences away - for example they can find deeper markets with similar shorting rules elsewhere in the world). We could have repeated this exercise with these companies listed in other jurisdictions as well (most of the literature we report on looks at US listings). Stripping out the effect of information flows, home market effects (market conditions in China), and regulation on these markets, the results would remain the same. ${ }^{28}$

\section{Conclusions}

We spent a long time looking at the fancier studies trying to figure out if corporate governance changes along the line of "the canon" results in higher shareholder returns. The canon represents the practices encouraged by the OECD Principles of Corporate Governance and largely adopted (but not on a one-to-one or perfect basis) the Hong Kong Stock Exchange's Listing Rules. Once we remove the regressions and other theory-laden approaches, we find that a simple differencesin-differences approach yields an estimated 7\% gain in shareholder returns for Mainland companies adopting Hong Kong's corporate governance practices (and other features unique to a Hong Kong listing). Using the simplest method available (simply calculating a 7\% bump to all Mainland companies' valuations), adopting the canon would generate $\$ 330$ billion around 2016$17 .^{29}$ Looking at the way the way the distribution of shareholder returns differs before and after reform shows a proportion of firms' shareholder value declining. Yet, the overall (average) increase more than offsets these losses - suggesting that the canon does not help all companies. Further research could usefully identify which companies such reform would hurt...and why.

\section{References}

Amoako-Adu, Ben and Vishaal Baulkaran. (2007). The Effects of the Sarbanes-Oxley Act and Canadian Equivalent, Bill 198/CSA Rules, on Canadian Cross-Listed Stocks. Available online.

Ang, James, Zhi-Qian Jiang, and Chao-Peng Wu. (2016). Good Apples, Bad Apples: Sorting Among Chinese Companies Traded in the U.S. Journal of Business Ethics 134(4). Available online.

Bai, Chong-En, Qiao Liu, Joe Lu, Frank Song, and Junxi Zhang. (2004). Corporate Governance and Market Valuation in China, Journal of Comparative Economics 32(4). Available online.

Beatty, Randolph, Hai Lu, Wei Luo. (2013). The Market for “Lemons”: A Study of Quality Uncertainty and the Market Mechanism for Chinese Firms Listed in the US. Available online.

\footnotetext{
${ }^{28}$ A very large literature exists on the reasons why Chinese shares listed abroad change price relative to dual listed and other shares. Our purpose does not consist in trying every out about these data... only to show that corporate governance matters. For readers interested in figuring out that informational and other factors play a small role in these shares' price movements relative to corporate governance should dated, but still relevant, results by Xu and Fung (2002) and Wang and Li (2004).

${ }^{29}$ The monetary value of $7 \%$ of market value depends on the market value at the time. Thus, delying reform could increase the nominal value of such reform (albeit decrease the real or time-adjusted value).
} 
Black, Bernard, Woochan Kim, Hasung Jang, and Kyung-Suh Park. (2008). European Corporate Governance Institute Finance Working Paper 103/2005. Available online.

Bris, Arturo, Neil Brisley, and Christos Cabolis. (2008). Adopting Better Corporate Governance: Evidence from Cross-Border Mergers. Journal of Corporate Finance 14(3). Available online.

Chen, Jean, Xin-Sheng Cheng, Stephen Gong, and You-Chao Tan. (2014). Voluntary NonFinancial Disclosure. Corporate Governance and Investment Efficiency. Available online

Chen, Jean and Hai-Tao Zhang. (2012). The Impact of the Corporate Governance Code on Earnings Management - Evidence from Chinese Listed Companies. European Financial Management 20(3). Available online

Cheung, Yan-Leung, Ping Jiang, Piman Limpaphayom, and Tong Lu. (2008). Does Corporate Governance Matter in China, China Economic Review 19(3), 2008, available online.

Cheung. Yan-Leung, Ping Jiang, and Wei-Qiang Tan. (2010). A Transparency Disclosure Index Measuring Disclosures: Chinese Listed Companies. Journal of Accounting and Public Policy 29(3). Available online.

Cheung, Yan-Leung and Ping Jiang, Piman Limpaphayom and Tong Lu. (2010b). Corporate Governance in China: A Step Forward. European Financial Management 16(1). Available online.

Cheung, Yan-Leung, Thomas Connelly, Priman Limpaphayom and Lynda Zhou. (2007). Do Investors Really Value Corporate Governance? Evidence from the Hong Kong Market. Journal of International Financial Management and Accounting 18(2). Available online.

Chinastockfraud.com. (2014). Chinese Stock Fraud, Beware of Chinese Stock Scams -They Are Real: Understand Chinese Stock Frauds. Available online.

Choudhury, Barnali. (2016). Social Disclosure. Berkeley Business Law Journal 13(1).

Claessens, Stijn, Corporate Governance and Development, World Bank Research Observer 21(1), 2006, available online.

Clarke, Donald. (2015). The Bonding Effect in Cross-Listed Chinese Companies: Is it Real? GWU Law School Public Law Research Paper No. 2015-55. Available online.

Cogman, David and Gordon Orr. (2013). How they fell: The collapse of Chinese cross-border listings. McKinsey \& Co. publication Available online.

Crawford, Rebecca. (2009). Corporate Governance Reform: How to Promote the Long-Term Health and Value of U.S. Corporations. NYU Journal of Law \& Business 5. Available online.

Darrough, Masako. (2015). The Spillover Effect of Fraud Allegations Against Chinese Reverse Mergers, 2015, available online. 
Doidge Craig, Andrew Karolyi, and Rene Stulz. (2009). Has New York become less competitive than London in global markets? Evaluating foreign listing choices over time. Journal of Financial Economics 91(3), 2009, available online.

Dong, Min-yue and Qing-mei Xue. (2009). Local versus global: Corporate governance practices in Chinese domestic and overseas companies. International Journal of Disclosure and Governance 6(4). Available online.

Dutillieux, Wouter and Marleen Willekens. (2009). The Impact of SOX On Earnings Quality Outside the U.S: Evidence from Belgian Subsidiaries of U.S. Listed Companies. Catholic University of Leuven Department of Accounting, Finance and Insurance Working Paper 0725. Available online.

Engel, Ellen, Rachel Hayes, and Xue Wang. (2007). The Sarbanes-Oxley Act and Firms' GoingPrivate Decisions. Journal of Accounting and Economics 44(1-2). Available online.

Epps, Ruth and Tariq Ismail. (2009). Board of Directors' Governance Challenges and Earnings Management. Journal of Accounting \& Organizational Change 5(3). Available online.

Fan, Gang-Zhi, Zsuzsa Huszar, and Wei-Na Zhang. (2014). Corporate Governance in Chinese Real Estate Firms. IRES Working Paper Series IRES2014-006. Available online.

Firth, Michael, Oliver Rui and Wen-Feng Wu. (2011). Cooking the Books: Recipes and Costs of Falsified Financial Statements in China. Journal of Corporate Finance 17(2). Available online.

FTSE. (2016). FTSE Russell, FTSE Factsheet: FTSE China Share Class Indexes. Available online.

Grinstein, Yaniv, and Vidhi Chhaochharia. (2007). Corporate Governance and Firm Value: The Impact of the 2002 Governance Rules. Journal of Finance 62(4). Available online.

Grove, Hugh and Maclyn Clouse. (2013). Corporate Governance Standards in Cross-Border Investing: Lessons Learned from Chinese Companies Listed in the United States. Available online.

Gu, Wei. (2016). Scrutiny Greets Overseas-Listed Chinese Companies Returning Home to Relist. Wall Street Journal. Available online.

Guo, Lin, Liang Tang, and Shia-Wee Yang. (2013). Corporate Governance and Market Segmentation: Evidence from the Price Difference between Chinese A and H Shares, Review of Quantitative Finance and Accounting 41(2). Available online.

Hail, Luzi and Christian Leuz. (2008). Cost of Capital Effects and Changes in Growth Expectations around U.S. Cross-Listings. Wharton Financial Institutions Center Working Paper 06-19. Available online. 
Harris, Dan. (2016). Buying Stock in China’s Publicly Traded Companies: Good Luck With That. China Law Blog. Available online.

HKICPA. (2012). A Guide on Better Corporate Governance Disclosure. Available online.

Holcomb, John, Corporate Governance: Sarbanes-Oxley Act, Related Legal Issues, and Global Comparisons. Denver Journal of International Law and Policy 32(2). Available online.

Hong Kong Exchange. (2010). Consultation Paper on the Review of the Code on Corporate Governance Practices and Associated Listing Rules. Available online.

Hornstein, Abigail. (2013). The impact of local governance institutions on foreign market listings: The case of Chinese firms. China Economic Review 29. Available online.

Hostak, Peter, Emre Karaoglu, Thomas Lys and Yong Yang. (2013). An Examination of the Impact of the Sarbanes-Oxley Act on the Attractiveness of US Capital Markets for Foreign Firms. Review of Accounting Studies 18(2). Available online.

Izurieta, Alex. (2017). Economic Models That Reality Can No Longer Afford. Institute for New Economic Thinking Working Paper. Available online.

Klautzer, Lisa. (2013). Can Economic Openness Inspire Better Corporate Governance? An Exploration of the Link between Openness and Corporate Governance based on the Asian Experience. RAND RGSD-310. Available online.

Kreuzroads. (2013). Global List of Chinese Stock Frauds. Available online.

Lawrence, Alastair. (2013). Individual Investors and Financial Disclosure. Journal of Accounting and Economics 56(1). Available online.

Lee, Charles, Kevin Li and Ran Zhang. (2015). Shell Games: The Long Term Performance of Chinese Reverse Merger Firms. The Accounting Review 90(4). Available online.

Lee, Charles, Kevin Li, and Ran Zhang. (2014). Shell Games: The Long Term Performance of Chinese Reverse Merger Firms. Stanford School of Business Working Paper. Available online.

Lee, Jung-wha and Zhi-hua Zhang. (2011). Ownership Structure, Corporate Governance and Firm Value: Evidence from Chinese Listed Companies. Finance and Corporate Governance Conference 2011 Paper. Available online.

Li, Shan, Paul Brockman and Ralf Zurbruegg. (2015). Cross-listing, firm-specific information, and corporate governance: Evidence from Chinese A-shares and H-shares. Journal of Corporate Finance 32. Available online.

Lin, Chen, Yue Ma, and Dong-Wei Su. (2009). Corporate Governance and Firm Efficiency: Evidence from China's Publicly Listed Firms. Managerial and Decision Economics 30(3). Available online. 
Lin, Jun and Ming Liu (2009). The Impact of Corporate Governance on Auditor Choice: Evidence from China. Journal of International Accounting, Auditing and Taxation 18. Available online.

Litvak, Kate. (2014). Defensive Management: Does the Sarbanes-Oxley Act Discourage Corporate Risk-Taking? University of Illinois Law Review. Available online.

Lo, Agnes, Raymond Wong, and Michael Firth, Can Corporate Governance Deter Management from Manipulating Earnings? Evidence from Related-Party Sales Transactions in China, Journal of Corporate Finance 16(2), 2010, available online.

Myers, Thomas and Lawrence Steckman. (2014). Financial Transparency and Disclosure: China Progess on Corporate Governance. Journal of International Business Ethics 7(1). Available online.

OECD. (2015). Principes of Corporate Governance. Available online.

Pan, Lee-Hsien, Chien-Ting Lin, and K.C. Chen. (2012). ADR Characteristics and Corporate Governance in the Greater China Region. Review of Development Finance 2. Available online.

Peng, Mike and Dane Blevins. (2014). Why Do Chinese Firms Cross-List in the United States? In Rasheed, Abdul and Toru Yoshikawa. The Convergence of Corporate Governance: Promise and Prospects. Palgrave.

Piotroski, Joseph and Suraj Srinivasan. (2008). Regulation and Bonding: The Sarbanes-Oxley Act and the Flow of International Listings. Rock Center for Corporate Governance Working Paper 11. Available online.

Shan, Yuan and Ron McIver. (2011). Corporate Governance Mechanisms and Financial Performance in China: Panel Data Evidence on Listed Non-Financial Companies. Asia Pacific Business Review 17(3). Available online.

Smith, Geoffrey. (2005). Sarbanes-Oxley and the Foreign Issuer: A Test of the Bonding Hypothesis. Available online.

Switzer, Lorne and Lin Hui. (2009). The Long-term Valuation Impact of Sarbanes-Oxley on U.S. vs. Foreign Firms. International Journal of Business Governance and Ethics 4(4). Available online.

Vagts, Detlev. (2003). Extraterritoriality and the Corporate Governance Law. American Journal of International Law 97(2). Available online.

Wang, Shu-ye and Jiang Li. (2004). Location of trade, ownership restrictions, and market illiquidity: Examining Chinese A- and H-shares. Journal of Banking \& Finance 28(6). Available online. 
Wintoki, Babajide. (2007). Corporate Boards and Regulation: The Effect of the Sarbanes-Oxley Act and the Exchange Listing Requirements on Firm Value, Journal of Corporate Finance 13(23). Available online.

World Bank. (2016). S\&P Global Equity Indices (annual \% change): Hong Kong, 2016. Available online.

World Bank. (2016b). S\&P Global Equity Indices (annual \% change): China. Available online.

Xi, Li and Holly Yang. (2016). Mandatory Financial Reporting and Voluntary Disclosure: The Effect of Mandatory IFRS Adoption on Management Forecasts. The Accounting Review 91(3). Available online..

Xu, Xiao-qing and Hung-Gay Fung. (2002). Information Flows across Markets: Evidence from China-Backed Stocks Dual-Listed in Hong Kong and New York. Financial Review 37, available online.

Yeh, Yin-Hua, Pei-Gi Shu, Tsun-Siou Lee, and Yu-Hui Su. (2009). Non-Tradable Share Reform and Corporate Governance in the Chinese Stock Market. Corporate Governance 17(4). Available online.

Yu, Xie. (2016). China likely to delist more problematic companies in 2016. South China Morning Post. Available online.

Zachariadis, Markos, Susan Scott and Michael Barrett. Exploring Critical Realism as the Theoretical Foundation of Mixed-Method Research: Evidence from the Economics of IS Innovations. Cambridge Judge Business School Working Paper 3/2010, 2010. Available online.

Zhang, Lin. (2012). The Status Quo of Corporate Governance of Chinese Listed Companies. In Zhang, Lin. Venture Capital and the Corporate Governance of Chinese Listed Companies. Springer.

Zhou, Jian, Ting-ting Zhang, and Sheng-chao Cui. (2011). Cross Listing, Corporate Governance and Corporate Performance: Empirical Evidence of Hong Kong-Listed Chinese Companies. Nankai Business Review International 2(3). Available online. 